\section{Nyttig om pårørendes situasjon og rettigheter}

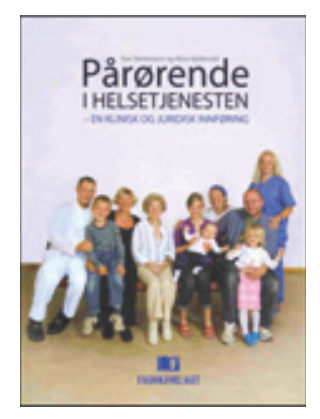

Kari Bøckmann, Alice Kjellevold

Pårørende i helsetjenesten

En klinisk og juridisk innføring. 387 s, ill. Bergen: Fagbokforlaget, 2010. Pris NOK 468 ISBN 978-82-450-0611-7

Målgruppene er først og fremst studenter i helse- og sosialfagene, på bachelor- og masternivå. Men den er er også myntet på ferdig utdannet personell og på pårørende og deres organisasjoner. Fremstillingen er noe preget av at forfatterne søker å favne en slik vid målgruppe. Deler av teksten er antakelig nokså selvfølgelige for enkelte. For andre, særlig studenter, kan alt virke både som viktig bevisstgjøring og som kilde til nyttige faktaopplysninger.

Stoffet er delt opp i 11 kapitler, det er i tillegg en litteraturliste på ca. 350 referanser. Kapitlene omhandler temaer som helsepersonells ansvar og plikter i forhold til pårørende, rettslig regulering av hvem som er nærmeste pårørende, helsepersonells dokumentasjon av arbeid med pårørende, og pårørendes rett til innsyn i journal og til ulike stønader og permisjoner. Noen handler om hvordan det er å være pårørende til en alvorlig syk, med beskrivelse av hvordan sykdom, kriser og sorg virker inn på dagliglivet, på familieliv og parforhold, på selvfølelse og skyldfølelse. Det er kapitler om foreldres situasjon når barn er alvorlig syke eller døende, og om situasjonen når barn eller ungdom er pårørende til noen med alvorlig sykdom.

Deler av teksten er nokså ordrike, men det finnes også nyttige sammenfatninger, bl.a. om hva som bør tas med i informasjonsmateriell til pårørende (s. 71), en opplisting av generelle råd til pårørende (s. 110-12), en oversikt over hva en bør være særlig oppmerksom på ved sorgreaksjoner (s. 115), og mye annet. Noen av sammenfatningene vil egne seg glimrende i prosedyrebøker for personell ved sengeposter på sykehus.

Bokens undertittel er «en klinisk og juridisk innføring». Jusen er spredd rundt i de forskjellige kapitlene. Det er bl.a. en redegjørelse om helsepersonells taushetsplikt overfor pårørende, og unntak fra taushetsplikten. Pasienters rett til å samtykke og medvirke ved helsehjelp er omhandlet, og hvilken lovregulering som gjelder når pasienten ikke er samtykkekompetent. Nærmeste pårørende skal informeres når det er fattet beslutning om at en pasient ikke har samtykkekompetanse, og ved spørsmål om inngripende helsehjelp skal nærmeste pårørende da få uttale seg om hva pasienten selv ville ønsket. Noen ganger kommer forfatterne med egne vurderinger av hva de mener kan forbedres i lovverket.

Boken kan bidra til økt forståelse for pårørendes situasjon, og til at det blir tatt mer hensyn til pårørende både i kliniske situasjoner og ved behandling av klager. Nylig har det vært mye mediefokus på pårørende $\mathrm{i}$ forbindelse med feilbehandling og klagesaker. Også der har det vært etterlyst at helsepersonell og tilsynsmyndigheter tar seg tid til å høre på pårørende. Ofte har disse viktige opplysninger å bidra med. Uansett er det viktig å ta hensyn til de pårørende. Dette er et bidrag til bevisstgjøring om at også pasientens nærmeste trenger vår oppmerksomhet.

\section{Steinar Aase}

Fylkesmannen i Telemark

Sosial- og helseavdelingen

Skien

og

Institutt for oral biologi

Universitetet i Oslo

\section{Svært godt om type 1-diabetes}

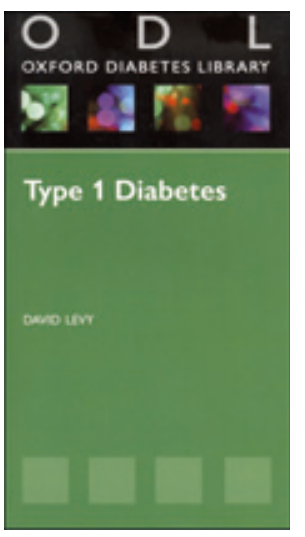

\section{David Levy \\ Type 1 diabetes}

175 s, tab, ill. Oxford: Oxford University Press, 2011. Pris GBP 13

ISBN 978-0-19-955321-1

Når man skal vurdere en slik bok, er det en del ting man sjekker om er med, og her er det meste der, og det aller meste er svært godt. Det står klokt om overgangen fra barn til ungdom og senere voksen, og behovet for ekstra gode rutiner. Det står klokt om behandling ved sykehusinnleggelse med gode råd om hvor viktig det er å passe på når pasienten ikke kan ta seg av insulindoseringen selv. Det gis uttrykk for (og det er jeg helt enig i) at pasienten, så langt det er mulig, selv kan ta seg av insulindoseringen (med egen blodsukkermåling) under sykehusopphold. Moderne mangeinjeksjonsbehandling er for komplisert å ordne for personalet, men enkelt for den som er vant til det. Betydningen av god blodsukkerkontroll ved alvorlige sykdommer som hjerteinfarkt, alvorlige infeksjoner og postoperativt, fremheves.

I England er det nærmest en selvfølge at pasienter med diabetes, og spesielt type 1-diabetes blir fulgt på sykehusenes diabetespoliklinikk. I denne boken poengteres også diabetessykepleiernes og diabetesteamets betydning. Mange steder er dette bra også i Norge. Type 1-diabetes er den mest kompliserte hormonmangelsykdom vi har, og også svært vanlig, men ikke så vanlig at man kan forvente at alle fastleger kan være gode medisinske rådgivere og lærere for dem.

Er det noe jeg savner? Ja, det vil det jo alltid være. Det står ikke noe om svangerskap, og det er trist. Piker og kvinner i fertil alder med diabetes må informeres om hvor viktig det er med god metabolsk kontroll fra unnfangelsen og gjennom hele svangerskapet. Under svangerskapet bør de følges av spesielle diabetesteam hvor også jordmor og gynekolog er med.

Noen av oss er i dag opptatt av hvilke problemer de har som har hatt type 1-diabetes i mange år. I boken finner vi en kort tabell som ikke gir noe annet enn demografiske opplysninger om dem som har hatt diabetes i over 50 år, og et kort kapittel om eldre type 1-pasienter. Det noen av oss i Norge kaller «diabetisk slitenhet», et begrep som i Norge ble introdusert av psykologen Jon Haug, er ikke omtalt. Mange år med stadig svingende blodsukkernivå, hypoglykemier, blodsukkermålinger og utallige insulininjeksjoner og i tillegg den psykiske belastning det er å leve med type 1-diabetes, kan meget vel ha spesielle omkostninger.

På 175 sider, svært små sider med liten skrift, har forfatteren samlet svært mye av vår kunnskap om type 1-diabetes. Han gir også mange nyttige figurer, og ikke minst gode referanser. I referansene har han inkludert PubMeds PMID-numre. Skriver man disse inn på PubMed-søkeren kommer sammendraget raskt opp. Er dette fremtidens måte å gi referanser på?

I forordet takkes Tore Julsrud Berg, som nå er strategidirektør for diabetesområdet i Helsedirektoratet, for hans grundige gjennomgang av manuskriptet.

Dette er en svært god bok, og alle som er interessert i og ønsker å hjelpe pasienter med type 1-diabetes, vil ha nytte og glede av å lese den.

\section{Jak Jervell}

Oslo 